\title{
Evaluation of knowledge in the field of proper skin care and exacerbating factors in patients with psoriasis
}

\author{
Monika Sawicka, Ryszard Żaba, Zygmunt Adamski \\ Department and Clinic of Dermatology, Poznan University of Medical Sciences, Poznan, Poland \\ Adv Dermatol Allergol 2022; XXXIX (2): 401-406 \\ DOI: https://doi.org/10.5114/ada.2021.107099
}

\begin{abstract}
Introduction: Psoriasis is one of the most common dermatological diseases. It is characterized by a chronic course with periods of exacerbations and remissions. The recurrent nature of the disease and the influence of environmental factors on its course require the patients not only to be treated but also to have knowledge of prophylaxis and proper skin care.

Aim: Obtaining information on the level of knowledge of patients suffering from psoriasis in the field of triggering factors and proper skin care.

Material and methods: A total of 130 patients with psoriasis participated in the study. The research tool was the author's questionnaire addressed to patients.

Results: Research has shown that the main source of knowledge for people with psoriasis was the Internet (85\%). Only $17 \%$ obtained information about the disease from medical personnel. The respondents were aware of the negative impact of only some environmental factors, such as: injuries (63\%), stimulants (77\%), stress (95\%), and infections (69\%). Most subjects attributed the therapeutic effect to brine baths (74\%). Usually the patients were aware of the oiling (85\%) and moisturizing (33\%) effects of emollients on psoriatic lesions. Only $46 \%$ of the respondents obtained a positive test result. Demographic variables correlated with the level of knowledge.

Conclusions: The knowledge of psoriasis patients about exacerbating factors and proper skin care is insufficient.
\end{abstract}

Key words: psoriasis, knowledge, awareness, prophylaxis, environmental factors, skincare.

\section{Introduction}

Psoriasis is a non-infectious, recurrent, inflammatory dermatosis of the skin, joints, and nails [1-3]. In Poland, about $2 \%$ of the population suffers from psoriasis [4, 5]. The disease equally affects both women and men. The disease is caused by inheritance and genetic disorders [1, 6, 7]. The disease is characterized by excessive proliferation of skin cells and a disturbed keratinization process [7, 8].

The diverse clinical picture, which depends on the type and severity of the disease, may manifest the form of several individual plaques of erythematous-exfoliating nature, through patches, up to generalized invasion of $90 \%$ of the skin surface - so-called erythroderma [2, 9].

Environmental factors play an important role in the occurrence and exacerbation of psoriatic lesions [4, 10]. These include, i.a., stress, infections (bacterial, viral, fungal), endocrine disorders, use of systemic medications, skin injuries, improper diet (fried foods, red meat, hot spices, and sweets), and stimulants. Avoiding triggers and changing eating habits can significantly help the patient to control the disease [11].

For the treatment to be effective, the patient should have knowledge of basic skin care in psoriasis. Keratolytic substances play an important role in everyday care, and their task is to soften and dissolve the keratinized epidermis, which hinders the penetration of active ingredients contained in topical medications and cosmetics into the deeper layers of the epidermis [12]. In the course of psoriasis, abnormalities of the epidermal barrier are observed, so it is important that the patient during skin care uses emollients containing substances with an oiling effect (hydrocarbon oils, waxes, sterols, fatty acids, fatty alcohols, ceramides, phospholipids), moisturizing effect (glycerine, propylene glycol, urea 10\%, sorbitol, lactic acid, hydroxy acids, hyaluronic acid, dexpanthenol),

Address for correspondence: Monika Sawicka, Department and Clinic of Dermatology, Poznan University of Medical Sciences, Poznan, Poland, phone: +48 786872 576, e-mail: monikasawicka1995@gmail.com Received: 23.02.2021, accepted: 12.04.2021. 
and soothing effect (lidocaine, polidocanol, menthol, camphor) $[12,13]$.

Chronic skin diseases significantly reduce the quality of life of patients. They have a negative impact on personal and professional functioning and also make establishing interpersonal relationships difficult. The disease accompanies patients throughout their lives. However, it is possible to control its symptoms. In order to obtain the longest possible periods of remission, the patient must not only follow the recommended treatment, but also have knowledge of the triggering and exacerbating factors as well as proper care of psoriatic skin. Strict adherence to recommendations may contribute to the desired therapeutic effect, increased response to treatment, prevention of heart disease, and improvement of the quality of everyday life $[1,6,9]$.

\section{Aim}

The main purpose of this work was to determine whether people suffering from psoriasis have knowledge in the field of proper skin care and factors affecting the exacerbation of the disease. In addition, examining the relationship between selected demographic variables (gender, place of residence, education, advanced treatment, hospitalization, self-assessment) and the patients' knowledge.

\section{Material and methods}

The study was conducted on a group of 130 subjects suffering from various types of psoriasis. It was confirmed by medical examination, dermatological examination, interview, and physical examination. The study was based on the author's questionnaire [14], which consisted of 2 parts: the general part and the testing part, and it included a total of 32 questions. The general part consisted of 13 questions. The testing part, which evaluated patients' knowledge of exacerbating factors and proper care of psoriatic skin, consisted of 19 questions. Both the general and the testing part consisted of single-choice and multiple-choice questions. In the testing part, each question was scored. The subject could get a maximum of 37 points. To assess the knowledge of patients, a score threshold of 22 points (60\%) was established.

The study in the form of an anonymous questionnaire addressed to women and men was carried out at the Department and Clinic of Dermatology of the Poznan University of Medical Sciences and online in 2 groups:

- Psoriasis/psoriasis support group;

- Psoriasis from a different perspective.

Individuals suffering from psoriasis were informed about the purpose of the study and the possibility of voluntary participation in it. The research was conducted in the period from 1.12.2019 to 26.03.2020.

\section{Statistical analysis}

In order to investigate the interrelations, statistical analyses were performed using the IBM SPSS Statistics 23 package. Student's t-test, U-Mann-Whitney test, Kruskal-Wallis test, and $\chi^{2}$ test were analysed for the frequency of responses selected by the subjects. The level of statistical significance was $\alpha=0.05$. It was assumed that the results at the significance level of $0.05<p<0.1$ were significant at the level of the statistical trend.

\section{Results}

A total of 130 individuals suffering from various types of psoriasis participated in the study, comprising $85 \%$ female subjects and $15 \%$ male subjects. The age of the subjects ranged from 18 to 70 years. The largest group of subjects (40\%) included individuals aged 31-51 years, while the smallest group of subjects (12\%) included individuals aged $51-70$ years. Among the subjects, the largest group of $27 \%$ included people living in rural regions. Forty-seven per cent of respondents had secondary education, $42 \%$ had higher education, $8 \%$ had vocational education, and 3\% had lower secondary education. The largest group included people suffering from plaque psoriasis (65\%). Local treatment was used by $76 \%$ of respondents, systemic treatment by $12 \%$, biological treatment by $8 \%$, and phototherapy by $4 \%$. In the group of 130 subjects, $38 \%$ of patients were hospitalized due to psoriasis. Seventeen per cent of patients obtained information about the disease from medical personnel. The main source of information on exacerbation factors and psoriatic skin care was the Internet (85\%). Forty-nine per cent of patients assessed their knowledge about the disease as sufficient.

The testing part of the questionnaire, consisting of 19 questions, was aimed at assessing the knowledge of patients. The subject answering questions on skin care and factors that result in worsening of the disease, had to obtain a minimum of 22 points to be qualified as an individual with the awareness. The respondents were asked about the impact of skin injuries on worsening of the disease. The vast majority of respondents (63\%) answered the question correctly, choosing the answer yes. Thirty-seven percent of the surveyed people gave an incorrect answer. The safest method of hair removal is to shave with a razor with an appropriate lubricant to make the razor glide. The question concerning the safest method of hair removal was answered correctly by $35 \%$ of patients. Any stimulants, such as alcohol and cigarettes, lead to exacerbation of psoriasis lesions. The vast majority (77\%) were aware of the negative impact of stimulants on health. The respondents stated that the following factors are responsible for the exacerbation of the disease: $95 \%$ stress, $69 \%$ infections, $68 \%$ improper diet, $49 \%$ certain medications, $36 \%$ increased body mass index (BMI), 35\% endocrine disorders, 2\% phototherapy, 
and $0.8 \%$ each brine baths and emollients. It was a multiple-choice question in which the subject could score a maximum of 6 points. Correct answers are as follows: stress, poor diet, increased BMI, certain medications, infections e.g. pharyngitis, endocrine disorders (Figure 1).

The test also included a question about products that have a positive effect on the condition of the skin in psoriasis. Most people (83\%) attributed the positive effect on the skin to vitamin $A$. The respondent could receive a maximum of 6 points. The correct answers were: vegetable oils, olive oil, vitamin A and E, omega-3 fatty acids, fish oil, and cereal grains. Subjects did not know the answer to this question (Figure 2).

The patients had knowledge about the positive effect of therapeutic baths on psoriasis lesions. Seventy-four per cent of the respondents chose the answer brine bath as 1 of the 3 correct answers. When asked about the effects of the emollient, the respondents usually answered the question correctly. A large group of people believed that emollient preparations demonstrated oiling properties (85\%) and retained water in the skin (33\%). People with psoriatic skin eruptions should avoid such preparations as soap or bath gel, because these cosmetics cause dry skin. The bath should take place in lukewarm water for a maximum of 15 min with the use of delicate, oiling emollient products. Fifty-eight percent of patients answered the question about the drying effect of soap correctly, while only $48 \%$ of the respondents knew that emollients should be used for bathing in psoriasis. Only

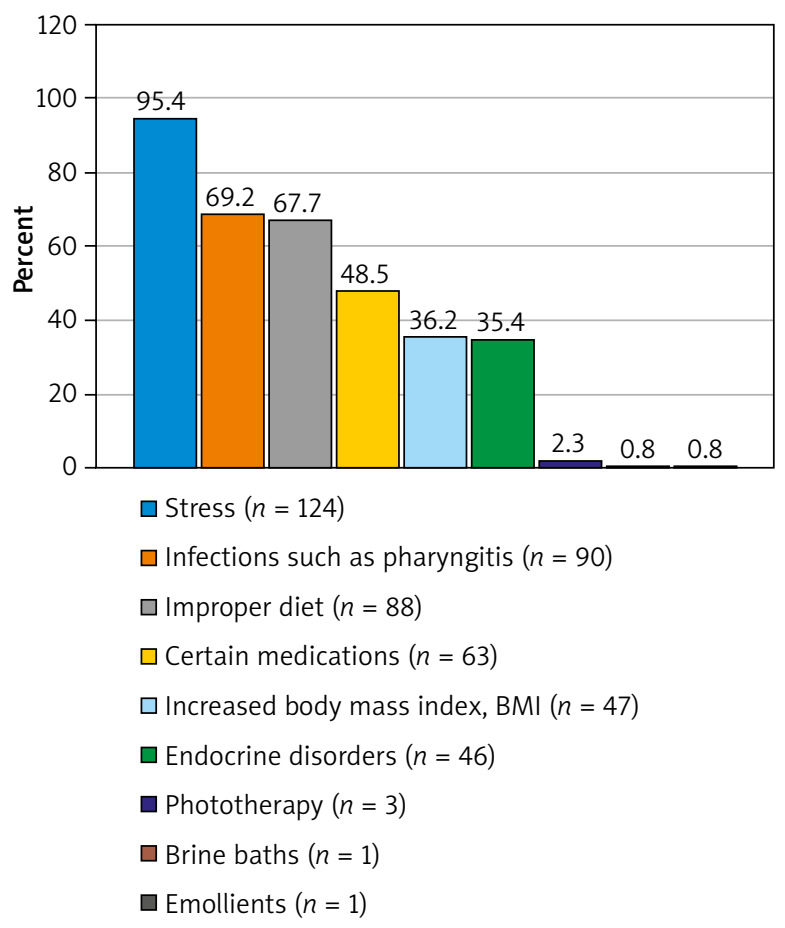

Figure 1. Percentage distribution of answers to the question about factors causing exacerbation of the disease [14]
$28 \%$ believed that the water should be lukewarm and $62 \%$ declared that the bath should last $15 \mathrm{~min}$. The vast majority (83\%) of patients believed that in course of psoriasis, emollients should be used in the form of a lotion or body cream. However, only $15 \%$ knew that they should be used on regular basis, at least twice a day. Fifty-six percent of the respondents correctly answered the question regarding the sequence of applying the topical drug and the skin care product, while the majority (60\%) did not know the answer to the question about the time between the application of the emollient and the topical medication. Most of the respondents (73\%) believed that emollients have a moisturizing effect and (71\%) reduce skin peeling. Seventy-two percent of patients believed that the use of emollients is necessary in psoriasis. Apart from dermatological treatment, in the patients' opinion (68\%), the most important thing is to select the appropriate skin care products. It was a multiple-choice question, and all of the answers were correct. The subject could score a maximum of 4 points (Figure 3 ).

The subject could score a maximum of 32 points in the test on the knowledge of exacerbating factors and the care of psoriatic skin. A scoring threshold of $60 \%$ was established in order to assess the patients' knowledge. Only 60 subjects exceeded the threshold, which constituted $46 \%$ out of 130 respondents. Despite the fact that individual subjects provided correct answers to the questions, the overall result was moderately satisfactory (Figure 4).

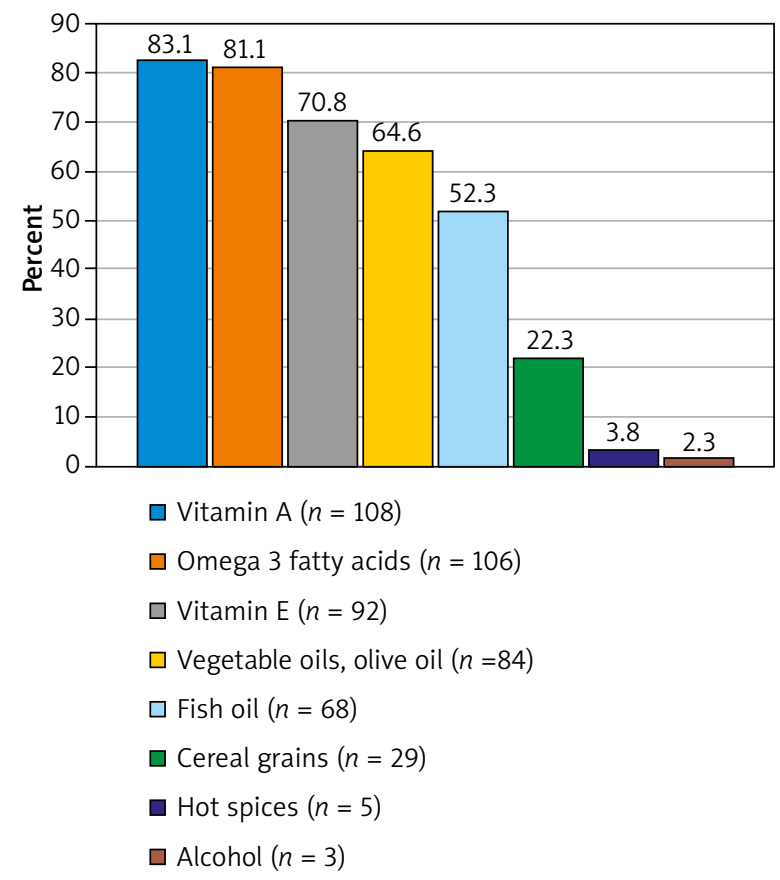

Figure 2. Percentage distribution of answers to the question regarding products positively influencing the condition of the skin in psoriasis [14] 


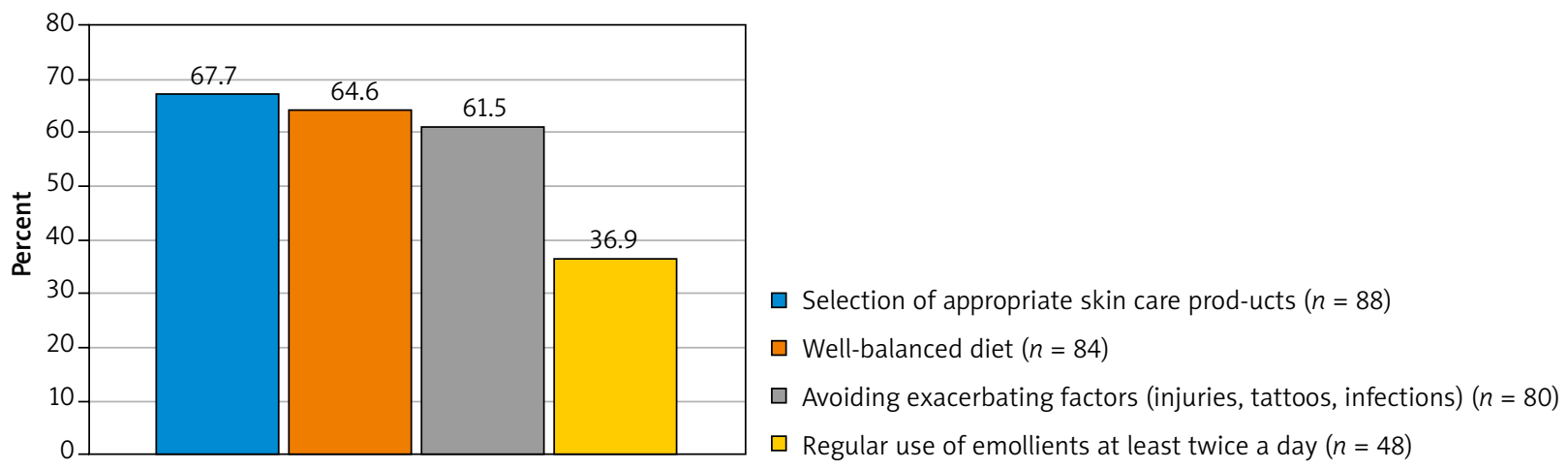

Figure 3. Percentage distribution of responses to the question about proper psoriasis skin care practices [14]

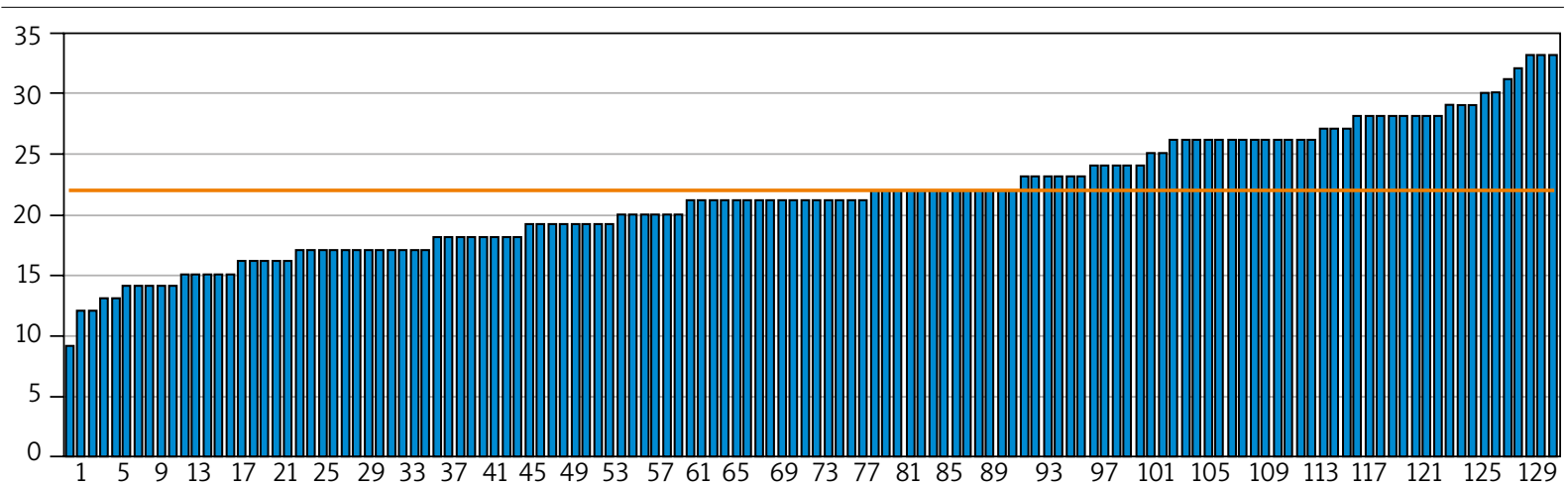

Figure 4. The results of the test checking the patients' knowledge about exacerbating factors and appropriate care of psoriatic skin [14]

In order to verify the interrelation between selected demographic variables (gender, place of residence, education, advanced treatment, hospitalization, self-assessment) and the patients' knowledge, multiple frequency analysis was performed using $\chi^{2}$ tests. Statistical analysis showed several significant correlations. Female gender, place of residence, education, advanced treatment, hospitalization, and positive self-assessment of knowledge were significantly more often associated with a higher level of knowledge among the subjects.

\section{Discussion}

Skin diseases, in particular of chronic and recurrent nature, require patient education both in the area of treatment and proper skin care. Long periods of remission can be achieved when the right treatment is applied, unfavourable factors causing exacerbation of lesions are avoided, and proper skin care is used. Awareness of the extent of the disease gives the patient the ability to avoid exacerbating factors and to select skin care products correctly, which may affect the frequency of relapses and the number of hospitalizations. Making the patients familiar with their condition may help in self-acceptance, which in turn is associated with improvement in the quality of life and interpersonal relations.
In periods of relapse, psoriasis may take a severe form. In such cases, patients are often hospitalized. For the therapy to be effective, it must be continued by the patient at home. In this case, the recommendations provided by medical personnel play a key role. The studies by Wyderka and Darowska [15] showed that $96 \%$ of the respondents declared that they had obtained information about further therapeutic management of the diseases [15]. Our own study showed a different result: only $17 \%$ of the respondents declared they obtained information from medical personnel. The different outcome could result from the way the information was provided, which was not always clear and understandable to the patient [16]. According to Wahl et al. [17], having knowledge is based on the philosophy of partnership between the patient and the doctor. Renzi et al. [18] noted that patients with extensive knowledge of the disease were more satisfied with the treatment than those who were less knowledgeable [18].

Studies have shown that the main source of information related to the disease was the Internet (85\%) and a dermatologist (60\%). These results were confirmed in the study conducted by Borek et al. [19], in which 63\% of respondents declared obtaining information via the Internet [19]. Kowalczuk et al. [11] showed that patients 
obtain elementary knowledge from a doctor [11]. Mueller et al. [20] studied the quality and reliability of educational videos related to psoriasis posted on YouTube. The authors proved that $20 \%$ of the content was true, $32 \%$ was useful, while the rest was considered dangerous and misleading. Therefore, patients should look for information related to the disease from proven sources such as books, magazines, or scientific websites [20].

The questionnaire prepared for the purposes of the study resembled a knowledge test relating to prophylaxis. In 2013, Wahl et al. [17] conducted a similar study that checked patients with psoriasis in terms of their level of knowledge about the disease and its treatment. In their questionnaire, they prepared questions about disease triggers and proper skin care techniques. Wahl et al. showed that $71 \%$ of patients had knowledge of the negative effect of injuries on the skin condition in psoriasis [17]. The people participating in our study (63\%) also knew that a break in the epidermis is associated with the formation of new psoriatic lesions. Bardazzi reached similar conclusions in 2014, when he examined patients with psoriasis in Italy [21].

A large group of patients (77\%) were aware of the negative impact of stimulants (cigarettes, alcohol) on the deterioration of the skin condition in psoriasis. This result was confirmed by Bardazzi's research [21]. Moreover, Chodorowska et al. [22] noted that patients suffering from psoriasis who abuse all kinds of substances fail to follow the recommendations and treatment much more often [22].

A number of conducted studies have classified stress as one of the main factors influencing the development and course of the disease. Wahl et al. [17] showed that $95 \%$ of patients consider stress to be one of the factors responsible for the worsening of the disease [17]. We obtained the same result in our study.

The environmental factors influencing the activation of the disease include infections and medications. Sixtynine percent of the respondents had knowledge about the influence of infection on the course of the disease, and $48 \%$ of individuals knew about the negative effect of certain drugs. In the study conducted by Wahl, $62 \%$ of patients knew about the influence of infection, and only $11 \%$ of the respondents knew about the negative effect of drugs on the exacerbation of the disease [17].

The studies conducted by Kwiatek and Chodorowska [23] proved that individuals with psoriasis demonstrated a knowledge deficit in terms of information about recommended diet [23]. The questionnaire measured the level of patients' knowledge regarding information about the products they consumed that had a positive effect on the condition of the skin. We noticed that the patients considered vitamins $\mathrm{A}$ and $\mathrm{E}$ and omega 3 fatty acids to be the best for the condition of the skin.

Nurturing effects in psoriasis lesions can be obtained with the help of therapeutic baths. Seventy-four percent of the respondents knew about the beneficial effects of brine baths on psoriatic skin eruptions. Pawelczyk et al. [24], who analysed the frequency of using this type of treatment, obtained similar results [24].

Patients with psoriatic skin eruptions should appropriately select preparations used for bathing. Most soaps and gels cause the skin to dry and tighten, which negatively affects the condition of the lesions. Fifty-eight percent of respondents had knowledge about the drying effect of body wash cosmetics. Similar results were obtained by Bardazzi et al. [21].

Emollients complement the local treatment. These preparations demonstrate oiling, moisturizing, softening, soothing, and alleviative properties. They minimize itching and peeling of the skin. Usually, the examined people had knowledge about the positive effect of emollients on the skin condition in psoriasis. The results were confirmed in the studies conducted by Wahl et al. [17] and Sierakowska et al. [25].

In order to assess the knowledge of patients, a score threshold of 22 points (60\%) was established, which patients had to reach in order to qualify for the group of people with knowledge about triggers and proper skin care. Despite the fact that the patients provided correct answers to individual questions, only $46 \%$ of patients exceeded the threshold of $60 \%$. The questionnaire contained questions related to various areas of knowledge, and the high number of incorrect answers indicates that not all the details of the disease were known to patients. The authors of previous studies came to the same conclusions. Wahl et al. [17] observed gaps in knowledge in patients before the introduction of the educational programme [17]. Kowalczuk et al. [11] noticed that the most significant deficiencies in the patients' knowledge were observed in the sphere of prevention of psoriatic lesions [11]. Kwiatek and Chodorowska proved that the patients do not have knowledge about their own disease [23].

Statistical analysis showed that female gender, place of residence, education, advanced treatment, hospitalization, and positive self-assessment of knowledge were significantly more often associated with a higher level of knowledge among the subjects. Bardazzi et al. [21] proved that female gender corresponded to a high level of knowledge [21]. Variables such as gender, education, and disease advancement were confirmed by the results obtained by Wahl et al. [17]. Kowalczuk et al. [11] did not notice any relationship between gender, place of residence, duration of dermatosis, and the level of knowledge [11].

Numerous scientific reports as well as our own observations indicate that there is a high demand for education activities among patients suffering from psoriasis, in the areas of triggering factors and skin care. The effect of education on the level of knowledge among the patients with psoriasis was studied by Wahl et al. [17]. After training, patients demonstrated improved knowl- 
edge in comparison to the level at the beginning of the study [17]. The same results were obtained by Bubak et al. [26] when evaluating the value of education among the people suffering from psoriasis [26]. Wyderka and Darowska [15] proved that patient education could be helpful in mitigating the negative effects of the disease not only for the patients but also for their families [15]. The research by Kowalczuk et al. [11] showed that the introduction and popularization of educational programs would improve the quality of life among the patients suffering from psoriasis [11].

\section{Conclusions}

The main source of knowledge about the disease was the Internet. Patients do not have sufficient knowledge of the exacerbating factors and the proper care of pathological lesions. Women, patients with higher education, hospitalized patients, patients using systemic treatment, and those who believe that their knowledge is sufficient have more knowledge about the factors exacerbating the disease and proper care of psoriatic skin. Patients from rural regions have lower awareness of the disease. The introduction and popularization of educational programmes will improve the quality of life of individuals suffering from psoriasis.

\section{Conflict of interest}

The authors declare no conflict of interest.

\section{References}

1. Adamski Z, Neneman A. Łuszczyca zwyczajna. In: Praktyka dermatologiczna. Kaszuba A, Maj J (eds.). Termedia, Poznań 2016: 115-35.

2. Furter S, Jasch KC. Dermatologia. Majewski S (ed. Polish edn.). Elsevier Urban \& Partner, Wrocław 2009; 141-9.

3. du Vivier A. Atlas dermatologii klinicznej. Majewski S (ed. Polish edn.). Elsevier Urban \& Partner, Wrocław 2005; 69-86.

4. Kaszuba A, Uczniak S, Kaszuba A. Łuszczyca. In: Dermatologia geriatryczna. Kaszuba A, Szepietowski J, Adamski Z (eds.) Czelej, Lublin 2016; 171-205.

5. Padlewska K. Medycyna estetyczna i kosmetologia. PZWL, Warsaw 2014; 162-6.

6. Batycka-Baran A, Nockowski P, Baran W. Łuszczyca. In: Terapia w dermatologii. Szepietowski J, Baran W (eds.). PZWL, Warsaw 2019; 208-24.

7. Neneman A, Adamski Z. Zaburzenia rogowacenia. In: Dermatologia dla kosmetologów. Adamski Z, Kaszuba A (eds.). Edra Urban \& Partner, Wroclaw 2019; 111-3.

8. Romańska-Gocka K. Farmakoterapia łuszczycy. Farm Pol 2009; 65: 647-54.

9. Skubis-Zegadło J. Łuszczyca. In: Współczesna kosmetologia - Nowoczesne urządzenia. Wiśniewska I, Kuszkowska K, Łukasiewicz B (eds.). Atena, Warszawa 2012; 208-14.

10. Grono M, Mrozowska M, Salczyńska A. Wstęp do kosmetyki - podstawy anatomiczno-dermatologiczne w kosmetyce (Technik usług kosmetycznych). Nowa Era, Warsaw 2013; 219-21.
11. Kowalczuk K, Jankowiak B, Sekmistrz S, et al. Program edukacji pielęgniarskiej pacjentów z łuszczycą. Probl Hig Epidemiol 2008; 89: 258-63.

12. Krajewska J. Pielęgnacja skóry w łuszczycy. Lek w Polsce 2015; 25: 51-6.

13. Reszke R, Szepietowski J. Specjalistyczne podłoża dermatologiczne w terapii skojarzonej przewlekłych dermatoz. Forum Dermatologicum 2016; 2: 97-101.

14. Sawicka M. Analiza poziomu świadomości chorych na łuszczycę dotycząca prawidłowej pielęgnacji skóry oraz czynników wpływających na zaostrzenie choroby (badanie ankietowe). Praca magisterska. UMP, Poznań 2020.

15. Wyderka MI, Darowska J. Problemy pielęgnacyjne i społeczne u osób chorych na łuszczycę. Pieleg Pol 2016; 2: 214-9.

16. Walniczek P. Kompleksowa terapia w leczeniu chorych na łuszczycę. Współcz Pielęg Ochrona Zdr 2018; 7: 11-3.

17. Wahl KA, Moum T, Robinson SH, et al. Psoriasis patients' knowledge about the disease and treatments. Dermatol Res Pract 2013; 2013: 921737.

18. Renzi C, Di Pietro C, Gisondi P, et al. Insufficient knowledge among psoriasis patients can represent a barrier to participation in decision-making. Acta Dermatovenereol 2006; 86: 528-34.

19. Borek E, Sitek A, Kołodziej M. Potrzeby pacjentów z łuszczycą w Polsce - łuszczyca. Badanie pilotażowe opinii pacjentów przeprowadzone online w grupie pacjentów z łuszczycą (raport). Warszawa 2016.

20. Mueller MS, Jungo P, Cajacob L. The absence of evidence is evidence of non-sense: cross-sectional study on the quality of psoriasis-related videos on youtube and their reception by health seekers. J Med Internet Res 2019; 21: e11935.

21. Bardazzi F, Amerio P, Amoruso G, et al. Investigating psoriasis awareness among patients in Italy: validation of a questionnaire. Eur Rev Med. Pharmacol Sci 2014; 18: 3435-52.

22. Chodorowska G, Bryczek M, Dąbrowska-Członka M, Bartosińska J. W jakim stopniu chorzy na łuszczycę interesują się swoją chorobą? Badanie wstępne. Adv Dermatol Allergol 2006; 23: 186-91.

23. Kwiatek J, Chodorowska G. Poziom wiedzy o swojej chorobie pacjentów chorych na łuszczycę. Probl Hig Epidemiol 2007; 88: 360-4.

24. Pawlaczyk M, Korzeniowska K, Pielesiak A. Czy chorzy na łuszczycę i atopowe zapalenie skóry korzystają z leczenia uzdrowiskowego? Farm Wspótcz 2012; 5: 83-8.

25. Sierakowska K, Moroch A, Urbańska M. Ocena stanu wiedzy i świadomości pacjentów na temat stosowania kosmetyków pielęgnacyjnych w leczeniu łuszczycy. Pol J Cosmetol 2014; 17: 70-3.

26. Bubak C, Schaarschmidt LM, Schöben L, et al. Analyzing the value of an educational program for psoriasis patients: a prospective controlled pilot study. BMC Public Health 2019; 19: 1535. 